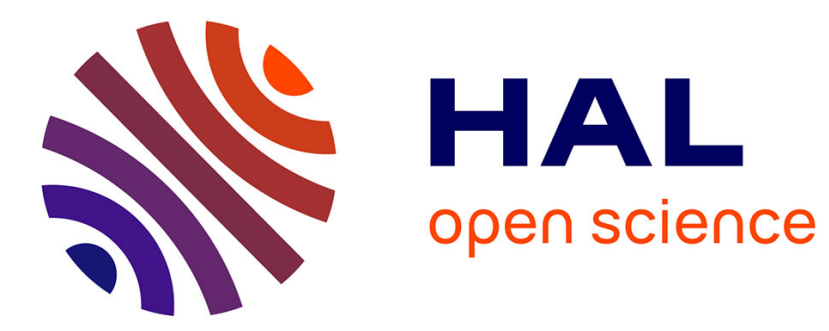

\title{
Genetic Analysis of Biomagnetic Crystal Formation
}

\author{
T. Matsunaga, N. Tsujimura, S. Kamiya
}

\section{To cite this version:}

T. Matsunaga, N. Tsujimura, S. Kamiya. Genetic Analysis of Biomagnetic Crystal Formation. Journal de Physique IV Proceedings, 1997, 07 (C1), pp.C1-651-C1-654. 10.1051/jp4:19971268 . jpa-00254978

\section{HAL Id: jpa-00254978 https://hal.science/jpa-00254978}

Submitted on 1 Jan 1997

HAL is a multi-disciplinary open access archive for the deposit and dissemination of scientific research documents, whether they are published or not. The documents may come from teaching and research institutions in France or abroad, or from public or private research centers.
L'archive ouverte pluridisciplinaire HAL, est destinée au dépôt et à la diffusion de documents scientifiques de niveau recherche, publiés ou non, émanant des établissements d'enseignement et de recherche français ou étrangers, des laboratoires publics ou privés. 


\title{
Genetic Analysis of Biomagnetic Crystal Formation
}

\author{
T. Matsunaga, N. Tsujimura and S. Kamiya* \\ Department of Biotechnology, Tokyo University of Agriculture \& Technology, 2-24-16, Naka-cho, \\ Koganei-shi, Tokyo 184, Japan \\ * TDK Akita Laboratory Corporation, 15 Aza-Gashomen, Hirasawa, Nikaho-machi, Yuri-gun, \\ Akita 018-04, Japan
}

\begin{abstract}
Magnetospirillum sp. AMB-1 is a freshwater magnetic bacterium which synthesizes intracellular particles of magnetite $\left(\mathrm{Fe}_{3} \mathrm{O}_{4}\right)$. A genomic DNA fragment required for synthesis of magnetic particles was previously isolated from a non-magnetic transposon Tn5 mutant. We have determined the complete nucleotide sequence of this fragment. The 2975 bp region contains two putative open reading frames (ORFs). One ORF, designated magA, encodes a polypeptide which is homologous to the cation efflux proteins, the Escherichia coli potassium ion translocating protein, $\mathrm{KefC}$, and the putative $\mathrm{Na}^{+} / \mathrm{H}^{+}$-antiporter, NapA, from Enterococcus hirae. Intracellular localization of the MagA protein was studied using magA - luc fusion proteins. The luc gene was cloned downstream of the magA hydrophilic C-terminal domain. The fusion protein was also detected on the surface of the lipid bilayer covering the magnetic particles. These results suggest that MagA is a membrane-bound protein. Vesicles which contained MagA protein exhibited iron accumulation ability. We consider that the MagA protein is an iron transporier involved in the synthesis of magnetic particles in AMB-1.
\end{abstract}

\section{INTRODUCTION}

Bacteria isolated from freshwater which synthesize intracellular magnetic particles consisting of magnetite include Magnetospirillum magnetotacticum MS-1 [2], Magnetospirillum sp. MGT-1 [9], Magnetospirillum sp. AMB-1 [8] and Magnetospirillum gryphiswaldense [15]. Phylogenetic analysis of 16S rRNA sequences of Magnetospirillum spp. has shown their close evolutionary relationships to some photosynthetic bacteria [3]. We are currently using AMB-1 as a model system for the study of magnetite biomineralization at the molecular genetic level [7]. The ecological significance of bacterial magnetite remains unclear and the mechanism of magnetite crystal formation has not yet been elucidated.

The magnetic particles of these spirilla are aligned in chains in the cells. Furthermore, each particle is covered with a thin lipid layer [4]. Magnetic particles from strain AMB-1 are also covered by organic membranes. In magnetic bacteria, a magnetic particle synthesis system was proposed [6], which involves (i) uptake of iron; (ii) transport of iron to the cytoplasmic space and across the magnetic particle membrane; (iii) precipitation of hydrated ferric oxide within vesicles; and (iv) phase transformation of the amorphous iron phase to magnetite, during both nucleation and surface-controlled growth. Several aspects of the general system remain unclear, for example, whether the ferric or ferrous ion is taken up and transported, and which proteins control the reactions in stages (iii) and (iv). The proteins and their genes have not yet been isolated or analyzed.

Previously, five non-magnetic mutants were generated by introduction of transposon $\mathrm{Tn} 5$ into the genome of Magnetospirillum sp. AMB-1 [7]. We present here genetic analysis of the $3 \mathrm{kbp}$ genomic region interrupted in a nonmagnetic mutant, NM5. This work represents the first report of the DNA sequence and putative product information of a gene thought to be involved in the magnetite biomineralization process.

\section{MATERIALS AND METHODS}

\subsection{Strains and growth conditions}

Escherichia coli $\mathrm{DH} 5 \alpha$ was used for cloning of genes. $E$. coli was cultured in Luria broth at $37^{\circ} \mathrm{C}$ after adding the appropriate antibiotics. Wild-type and mutant Magnetospirillum sp. AMB-1 were cultured in magnetic spirillum growth medium $\left(\right.$ MSGM)(1) at $25^{\circ} \mathrm{C}$ as described previously [8]. 


\subsection{Plasmids, DNA fragments and gene transfer}

The plasmid vector, pRK415 ( $\mathrm{Tc}^{\mathrm{r}}, \mathrm{lacZ}_{\mathrm{m}} \mathrm{mob}^{+}$) [5], which is a broad host range vector for Gram-negative bacteria, and can be introduced into Magnetospirillum AMB-1 by conjugation [7], was used. A 2975-bp EcoRI-BamHI genomic fragment containing the magA gene isolated from the genomic gene bank of wild-type AMB-1 was utilized in this study.

\subsection{Nucleotide sequence analysis}

Samples for sequencing were prepared from plasmid pCN5 [7], which contains the EcoRI fragment including Tn5, from NM5. The Tn5 flanking regions were cloned separately, and deletion series for sequencing were constructed. DNA sequencing was carried out by the dideoxy method [14] on plasmid templates, using the AmpliTaq cycle sequencing kit, and FITC-labeled primers (Takara Shuzo, Shiga, Japan) or primers synthesized on the basis of sequence information using a DNA synthesizer (ABI, Carson City, CA). An automatic DNA sequencing machine, DSQ-1 (Shimadzu, Kyoto, Japan), was used for running samples, detection of fluorescence, and determination of nucleotide sequence. All sequencing reactions were performed three times at least and on both strands. The computer software packages, DNASIS (Hitachi Software Engineering Co., Ltd., Kanagawa, Japan) and LASERGENE (DNASTAR Ltd. London, UK), were used for analysis of DNA and protein sequences.

\subsection{Cloning of uninterrupted wild type genomic fragment}

The wild type genomic EcoRI fragment of AMB-1 was isolated from a $\lambda$ ZAP gene bank and subcloned for sequencing. A 334 bp downstream of EcoRI fragment, which was isolated from BamHI genomic DNA bank of NM5 containing a kanamycin resistant gene derived from $\mathrm{Tn} 5$, was also sequenced.

\subsection{Detection of localized luciferase activity by gene fusion}

The luciferase activities of the cytoplasm, cell membrane and BMP (bacterial magnetic particle) cell-fractions of transconjugants were measured. The pKPL and pKML transconjugants were grown to stationary phase on MSGM containing $2.5 \mu \mathrm{g} / \mathrm{ml}$ tetracycline at $25^{\circ} \mathrm{C}$. Cells were harvested and resuspended in $10 \mathrm{mM}$ Tris buffer (pH 7.0). Harvested cells were broken by sonication, and BMPs were collected using a magnet [13]. Cells which were not lysed were separated from the cell debris by centrifugation at $5000 \mathrm{x} \mathrm{g}$ for $20 \mathrm{~min}$. Then the supernatant was ultracentrifuged at $96600 \mathrm{x} \mathrm{g}$ for $1.5 \mathrm{~h}$ to separate the membrane fraction as a precipitate from supernatant containing the cytoplasmic fraction. The cell membrane precipitate was washed twice, and suspended in buffer. The luciferase assay was carried out using PicaGene (Toyo Ink, Tokyo, Japan). A 20- $\mu 1$ sample was added to $100 \mu \mathrm{l}$ of substrate solution containing $470 \mu \mathrm{M}$ luciferin and $530 \mu \mathrm{M} \mathrm{ATP}$, and the luminescence of the mixture was measured. The luminescence of the luciferin-luciferase reaction was detected using a Luminescence Reader BLR-301 (ALOKA, Tokyo, Japan).

\subsection{Preparation of Vesicles and iron uptake measurement}

pTrc99A was employed for expression of a protein in $E$. coli DH5 $\alpha$. DH5 $\alpha$ transformant cells were utilized for preparation of vesicles following the protocol of Waser et al. [16]. Vesicles were suspended in TMSM buffer $(100 \mathrm{mM} \mathrm{Tris-HCl,} 5 \mathrm{mM}$ $\mathrm{MgSO}_{4}, 250 \mathrm{mM}$ sucrose, $50 \mathrm{mM}$ malate, $\mathrm{pH} 7.4$ ) to a final protein concentration of $10 \mathrm{mg} / \mathrm{ml}$, and supplemented with 330 $\mu \mathrm{M}$ ferrous ammonium sulfate $\left(\mathrm{FeSO}_{4}\left(\mathrm{NH}_{4}\right)_{2} \mathrm{SO}_{4} \cdot 6 \mathrm{H}_{2} \mathrm{O}\right.$; Mohr's salt) as an iron source, and $5 \mathrm{mM}$ ATP. At various times, $0.8 \mathrm{ml}$ aliquots were removed and centrifuged at $15,000 \mathrm{x}$ for $15 \mathrm{~min}$ to remove vesicles. The iron concentration of the buffer was measured using ferrozine, a spectrophotometric reagent for iron. Fifty $\mu \mathrm{l}$ of $60 \%$ hydroxylamine hydrochloride was added to $100 \mu \mathrm{l}$ of the samples as a reductant, and argon gas was sealed into sample tubes and incubated for $24 \mathrm{~h}$. Finally, $100 \mu \mathrm{l}$ of glacial acetic acid-sodium acetate buffer (4.2M, pH 6.0) and $200 \mu \mathrm{l}$ of $1 \%$ ferrozine were added, and the absorbance of sample solutions at $526 \mathrm{~nm}$ was measured spectrophotometrically.

\section{RESULTS}

\subsection{Sequence analysis of the genes which are needed to synthesize magnetic particles}

To search the genes which is needed to synthesize magnetic particles in AMB-1, a transposon mutagenesis using Tn5 was carried out. Five kanamycin-resistant AMB-1 mutants which did not synthesize the intracellular magnetic particles were 
obtained [7]. From one of these nonmagnetic mutants, NM5, the complete sequence of its 3-kilobase pair genomic region which contains two putative open reading frames was determined [11]. One open reading frame designated magA encodes a polypeptide which is homologous to the cation efflux proteins, such as KefC. KefC is the Escherichia coli potassium ion-translocating protein and consists of two domains. These two domains are a hydrophobic membrane domain and a strongly hydrophilic carboxyl terminus (Fig. 1).
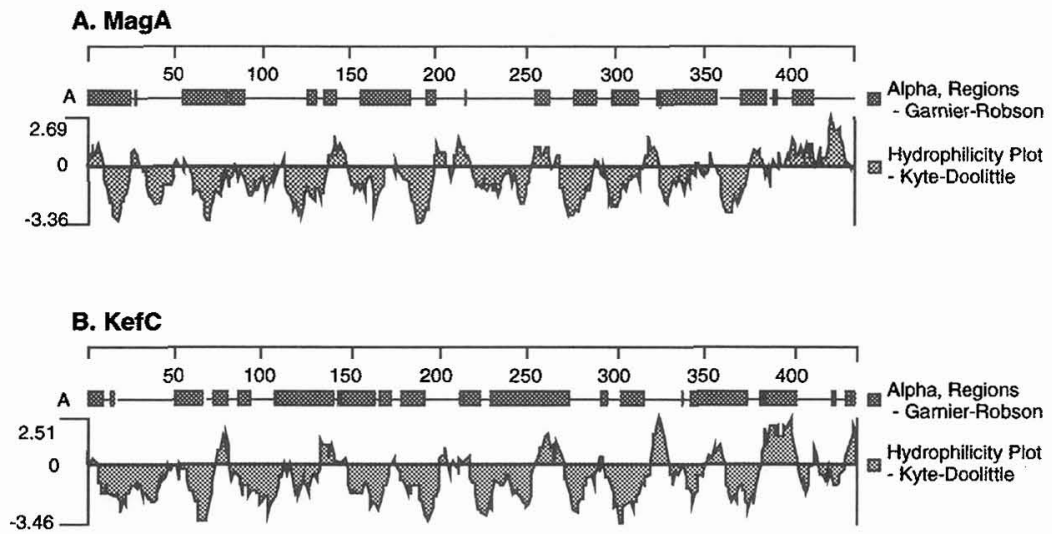

Fig. 1 Comparison of hydropathy plot between MagA and KefC.

\subsection{The intracellular localization of MagA protein}

The intracellular localization of MagA protein was studied using magA-luc fusion proteins. The $l u c$ gene, the firefly luciferase gene, was cloned downstream of the magA hydrophilic C-terminal domain. As a result, the luciferase activity was observed in the fraction of magnetic particle membrane and the MagA fusion protein was confirmed to be localized in the magnetic particle membrane (Table 1) [12]. In addition, the luc gene was also cloned downstream of the magA promoter and the effect of iron on the regulation of magA expression was examined. The transcription of $m a g A$ was found to be enhanced by low iron concentrations. These results indicated that the MagA protein is a membrane-bound protein.

\subsection{Iron transport activity of MagA protein}

A 2094 bp fragment from NcoI-BamHI digestion was connected to the multi-cloning site of pTrc99A to express the $\operatorname{mag} A$ gene in $E$. coli. This plasmid, designated pTMG5, was transferred into $E$. coli $\mathrm{DH} 5 \alpha$, and the transformed cells were utilized to prepare membrane vesicles. Iron transport by the magA gene product was verified by direct measurements of iron in membrane vesicles. When ATP was added to transformant vesicles, iron uptake could be observed (Fig. 2). However, when ATP was omitted, iron uptake was not observed (data not shown). This result shows that the $m a g A$ gene product functions as an iron transporter in the cytoplasmic membrane in $E$. coli and that the energy of transport is directly or indirectly coupled with ATP hydrolysis.
Table 1 Luminescence yield of cell fractions of transconjugant.

\begin{tabular}{lrr}
\hline & pKPL & pKML \\
\hline Cytoplasm & 35.2 & 0.9 \\
Cell membrane & 2.6 & 13.0 \\
Magnetic particle & 0.2 & 1.3 \\
\hline
\end{tabular}

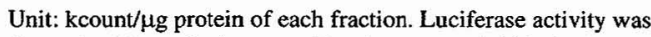
determined from the integrated luminescence yield in $3 \mathrm{~min}$.

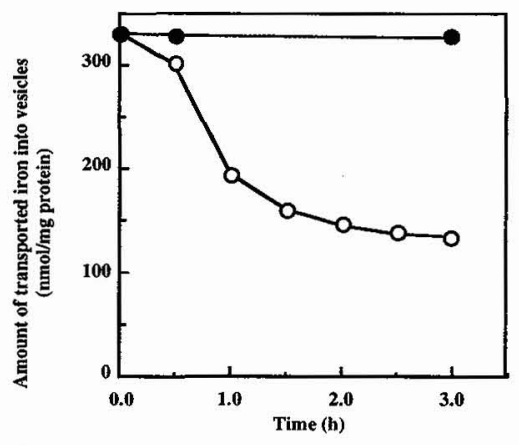

Fig. 2 Iron uptake by membrane vesicles. Membrane vesicles were prepared as described under "Materials and Methods, " and assayed in the TMSM buffer at a final protein concentration of $10 \mathrm{mg} / \mathrm{ml}$ supplemented with $330 \mu \mathrm{M}$ iron and $5 \mathrm{mM}$ ATP. The curves show change in iron concentration due to vesicles from the pTrc99A transformant of $E$. coli DH5a ( $\bullet$ and the pTMG5 transformant (O). 


\section{DISCUSSION}

The data presented above indicate that the ORF, magA, which was found in a mutagenized genomic fragment of NM5, encodes a putative protein, MagA, highly homologous to proteins of $E$. coli. KefC consists of two domains, a hydrophobic membrane binding domain and a strongly hydrophilic carboxy-terminus. The region homologous with MagA corresponds to the hydrophobic domain which is thought to be a potassium-translocating channel [10]. The sequence of hydrophobic amino acids could form eight to ten transmembrane $\alpha$-helices.

The putative MagA protein appears to be a membrane protein. The magA gene fusion is applicable to the biotechnological applications of BMPs. If an antibody could be expressed on BMPs by gene fusion, an immunoassay system using the antibody on BMPs would be feasible. Bioactive peptides and proteins on BMPs could be used as a novel drug delivery system. Furthermore, foreign proteins expressed on the surface of the BMPs can be easily separated and purified using magnets.

Iron is an essential element of the bacterial magnetic particle and must be translocated across the cell and magnetic particle membranes. Thus, iron transport has an important role in magnetic particle synthesis. Homology data and iron regulation suggest that the magA gene product is involved in iron transport. It has been confirmed by direct iron uptake measurements in membrane vesicles that the magA gene product functions as an iron transporter in $E$. coli. Moreover, this result verifies that the putative MagA protein is located in the inner membrane in $E$. coli. The MagA protein may function as an iron transport channel protein and be coupled with ATPase. In E. coli, ferric iron uptake has been well studied, and the transport of iron across the cytoplasmic membrane depends on ATP hydrolysis [1]. As to the putative MagA, two hypotheses may be put forward for the energy coupling. One is a direct driving of iron transport by ATPase, with a protein encoded by the second ORF in the cloned NcoI-BamHI restriction fragment functioning as the ATPase, or an ATPase derived from E. coli interacting with MagA. The other is an indirect ATPase coupling, with MagA functioning as an $\mathrm{Fe}^{2+/ \mathrm{H}^{+}}$antiporter driven by the proton motive force of $\mathrm{F}_{1} \mathrm{~F}_{0}$-ATPase, like the KefC protein of $E$. coli and the NapA protein of Enterococcus hirae [10, $16]$.

In conclusion, we report on a gene and a protein concerned with iron transport in a magnetic bacterium. Since interruption of the magA gene prevents magnetite synthesis in AMB-1, we suggest that the putative MagA protein may be localized in the membrane covering the magnetic particles in AMB-1 and may transport iron into the vesicles. In further work, biochemical analysis of the putative MagA protein will help elucidate a part of the mechanism of magnetic particle synthesis in this magnetic bacterium.

\section{References}

[1] Bagg A. and Neilands J.B., Microbiol. Rev. 51 (1987) 509-518.

[2] Blakemore R.P., Maratea D., and Wolfe R.S., J. Bacteriol. 140 (1979) 720-729.

[3] Burgess J.G., Kawaguchi R., Sakaguchi T., Thornhill R.H., and Matsunaga T., J. Bacteriol. 175 (1993) 6689-6694.

[4] Gorby Y.A., Beveridge T.J., and Blakemore R.P., J. Bacteriol. 170 (1988) 834-841.

[5] Keen N.T., Tamaki S., Kobayashi D., and Trollinger D., Gene 70 (1988) 191-197.

[6] Mann S., Sparks N.H.C., and Board R.G., Adv. Microb. Physiol. 31 (1990) 125-181.

[7] Matsunaga T., Nakamura C., Burgess J.G., and Sode K., J. Bacteriol. 174 (1992) 2748-2753.

[8] Matsunaga T., Sakaguchi T., and Tadokoro F., Appl. Microbiol. Biotechnol. 35 (1991) 651-655.

[9] Matsunaga T., Tadokoro F., and Nakamura N., IEEE Trans. Magnet. 26 (1990) 1557-1559.

[10] Munro A.W., Ritchie G.Y., Lamb A.J., Douglas R.M., and Booth I.R., Molec. Microbiol. 5 (1991) 607-616.

[11] Nakamura C., Burgess J.G., Sode K., and Matsunaga T., J. Biol. Chem. 270 (1995) 28392-28396.

[12] Nakamura C., Kikuchi T., Burgess J.G., and Matsunaga T., J. Biochem. 118 (1995) 23-27.

[13] Nakamura N., Hashimoto K., and Matsunaga T., Anal. Chem. 63 (1991) 268-272.

[14] Sanger F., Nicklen S., and Coulson A.R., Proc. Natl. Acad. Sci. USA 74 (1977) 5463-5467.

[15] Schleifer K.H., Schuler D., Spring S., Weizenegger M., Amann R., Ludwig W., and Kohler M., Syst. Appl. Microbiol. 14 (1991) 379-385.

[16] Waser M., Hess-Bienz D., Davies K., and Solioz M., J. Biol. Chem. 267 (1992) 5396-5400. 